WING-CHEUK CHAN AND HENRY C. H. SHIU

\title{
INTRODUCTION: \\ MOU ZONGSAN AND CHINESE BUDDHISM
}

As one of the most important thinkers in the development of modern Confucianism, Zongsan Mou 牟宗三 (1909-1995) is also one of the most influential Buddhologists in the twentieth century. His twovolume work, Foxing yu Boruo 《佛性與般若》received praise from Master Yinshun 印順 (1906-2005) as a milestone in contemporary Chinese scholarship on Buddhism. His major contributions in this field include the following: (i) identifying the notion of prajñ $\bar{a}$ (boruo 般若) from the Madhyamika perspective as the common teaching to all Mahāyāna Buddhist traditions; (ii) reconstructing Tiantai Buddhism as an ontological system; (iii) differentiating the Chan Buddhism of the Master (zushichan 祖師禪) from the Chan Buddhism of the tathägatagarbha (rulaichan 如來禪); and (iv) introducing a novel philological means of examining the authenticity of the Dacheng Zhi Guan Famen 《大乘止觀法門》.

Given the turbulent political development in China for more than a hundred and fifty years, only a few Chinese were able to devote themselves to conducting research on Buddhism. Yet, Buddhist studies in Japan was flourishing during this period with important findings. Given this, one can appreciate the depth and scope of Mou's works especially since his distinguished contributions were completely rooted in the Chinese context at a time when the country was in a great turmoil. While it is undeniable that Japanese scholars have produced unique studies that are quite beyond the reach of Mou, especially in the field of Yogācāra and Huayan Buddhism, it should be noted that Mou's research in Buddhism is primarily philosophical in character, whereas the Japanese studies were more philological and historical in nature. Indeed, the two styles of Buddhology neatly complement one another. Insofar as Mou's works remain unknown in the West, this special forum functions as a starting point that introduces his contributions to the field of Buddhist studies in the English-

WING-CHEUK CHAN, Professor, Department of Philosophy, Brock University. Specialties: phenomenology, Chinese philosophy, Yogācāra Buddhism. E-mail: wchan@brocku.ca HENRY C. H. SHIU, Assistant Professor, Department of Humanities, University of Toronto Scarborough. Specialties: Mahāyāna Buddhist philosophy, socially engaged Buddhism, Buddhism in Canada. E-mail: henry.shiu@utoronto.ca

Journal of Chinese Philosophy 38:2 (June 2011) 169-173

(C) 2011 Journal of Chinese Philosophy 
speaking world. We are grateful to Professor Chung-ying Cheng's initiative to gather the following articles on Mou's works in Buddhism. Hopefully these critical analyses of Mou's works from different perspectives in these articles will spark wider interests in understanding Mou's contributions in Buddhology and collaterally interests in contributions of Chinese Buddhism at large.

In this special forum, Jason T. Clower's article is on Mou's view of Mahāyāna Buddhism. Clower clearly demonstrates that Mou's understanding of Tiantai Buddhism is an extension of Mahāyāna Buddhism. One might recall that Mou was once engaged in the well-known debate with Master Yinshun. The latter criticized Tiantai's unique doctrine of Three Truths as resulting from a misinterpretation of Nagarjuna's doctrine of Two Truths, and hence claimed that this Tiantai teaching is "deceitful." For Mou, it was rather Master Yinshun who should be blamed for his failure to understand the consistency of these two doctrines. As an argument, Mou followed Zhiyi's 智顗 theory of syncretism which insists that the Buddha progressively taught his disciples in five periods. Such a classification also serves as a backbone for Clower's article as he explains Mou's view on how the Buddha progressively unveiled his teachings, the nature and experience of praj $\tilde{n} \bar{a}$, the doctrine of Buddha-nature as an ontological teaching, and the threefold distinction of the bodies of the Buddhas, and so on, through which both the strength and weakness of Mou's approach are carefully delineated. Critically, Clower's article seems to at first suggest that by today's standard in Western academia many questions can be raised concerning Mou's methodology. To begin with, one might challenge Mou's uncritical acceptance of Chinese translations of Buddhist texts and the authority of the Tiantai School. In identifying the Buddha as a "genuine sage" (understood somewhat in his own Neo-Confucian sense) and the Buddhist scriptures as the unquestionable authentic communications of the Buddha, Mou is accused of not providing an objective examination of the authenticity of Buddhist teachings. However, Clower also cautions us for the difficulties in interpreting Mou, especially with regard to his understanding of the Buddha's intentions and teachings. The core of the article is a reconstruction of a systematic view of Mou's Buddhology, to allow us to have a glimpse into the various "critical" functions Mou ascribes to the Buddhist teachings that the Tiantai tradition identifies as the last two phases of the preaching career of the Buddha.

Similar to Clower's concern with Mou's understanding of Buddhanature, Chun-Keung Kwan's article explores the ontological implications of this Mahāyāna doctrine. Contrary to Clower, Kwan starts with a detailed analysis of Mou's view on the controversies among the Tiantai masters. Although Kwan is sympathetic with Mou's "ontologi- 
cal" reading of Tiantai Buddhism, he complains that such an approach is mainly a Confucian concern. Kwan argues that originally Buddhism had no interest in the problem of the perfect good or the objective existence of the world after attaining Buddhhood. For Mou, there is a distinction between these immanent and transcendent ontology. In Mou's eyes, only in Tiantai Buddhism can one find a "transcendent ontology," which alone is able to offer an explanation of the source for both pure and impure dharmas. All this indicates, as Kwan underscores, Mou's attempt to construct an ontological reading in Tiantai Buddhism which is a fusion of Confucianism and Chinese Buddhism; this is facilitated by Mou's use of Kant's philosophy as a framework.

The doctrine of Buddha-nature likewise constitutes the core of Henry C. H. Shiu's and Andres Siu-Kwong Tang's articles, though coming from rather different perspectives. Henry Shiu focuses on Mou's interpretation of The Awakening of Faith. Henry Shiu is particularly interested in the legitimacy of employing the Sinitic concepts of “essence” ( $t i$ 體) and "function" (yong 用) to explicate the doctrine of the tathägatagarbha (rulaizang 如來藏). Given the fact that the text has been criticized for its probable Sinitic origin, Mou's confidence in relying on it might hardly survive the possible challenge from Japanese Critical Buddhism. In particular, it is difficult to philologically justify the authentic Buddhist status of such terms as "original enlightenment" (benjue 本覺) and the ti-yong 体用; philosophically, the interpretation of the doctrine of the tathägatagarbha in terms of the ti-yong might even give rise to the identification of the tathagatagarbha as a permanent substance. It would also suggest that Buddha-nature as an ontological entity is responsible for the rise of the world, a reading that is not far from the metaphysical monism as represented by Brahmanism. Historically, Mou, departing from the interpretation of his teacher Xiong Shili Xiong 熊十力 (1883-1968), tried to render this traditional interpretation of the doctrine of the tathagatagarbha in terms of the ti-yong as "instrumental." In this way, he attempted to show that The Awakening of Faith's doctrine of the tathägatagarbha is not an ontological monism, but merely a "skillful means" to pacify the audience who might view Buddhism as a kind of nihilism. As seen in Henry Shiu's article, for the sake of demonstrating the authenticity of this Buddhist teaching, Mou provided us with a new hermeneutics of the relationship between the tathaggatagarbha and the älayavijñāna (alaiyeshi 阿賴耶識) in terms of the "water and ripples" metaphor. Henry Shiu's article further compares Mou's interpretation with that which has been developed in the rNying ma School of Tibetan Buddhism. This discloses the surprising similarities of the two systems.

Whereas Henry Shiu mainly limits his discussion of the tathagatagarbha in The Awakening of Faith, Andres Tang closely 
investigates Mou's explanation of the Huayan Buddhist application of The Awakening of Faith in developing its own doctrine. After highlighting Mou's critique of the Huayan School from a Tiantai Buddhist standpoint, according to which the Huayan School is classified as a "distinctive" (bie 別), rather than a "perfect" (yuan 圓), teaching, Andres Tang first explains why Mou blamed the Huayan School for developing and elaborating various "speculative" doctrines. Second, in criticizing Mou's interpretation of the Huayan teaching of the "co-dependent origination of tathägatagarbha" as a transcendental analysis, Andres Tang turns to Wing-Cheuk Chan's argument for help. Following Chan, Andres Tang argues that, unlike The Awakening of Faith, the Huayan School goes beyond the transcendental-analytic approach, and is rather a form of dialectical philosophy in the Hegelian sense. As a result, as Andres Tang argues, one has to refute Mou's classifying the Huayan School as a distinctive teaching.

Wing-cheuk Chan's article aims at providing an appraisal of Mou's employment of the Buddhist framework in reconstructing Confucianism. Chan begins with a critical analysis of Mou's construal of the distinction between Tiantai Buddhism and the doctrine of the tathāgatagarbha as represented by The Awakening of Faith. In this context, Chan also indicates differences between Tang Junyi's 唐君毅 (1909-1978) and Mou's Neo-Confucianism. In contrast to Mou, Tang identifies Huayan Buddhism as the pinnacle of Chinese Buddhism. Such preference of Huayan over Tiantai paves the way for Tang to develop his absolute-idealist Confucianism. More importantly, Chan argues that, unlike Tang, there is an internal conflict in Mou's "integration" of Tiantai Buddhism and Confucianism. This is precisely shown in Mou's appreciation of the Tiantai perfect teaching, yet undermining the doctrine of tathägatagarbha as a distinctive teaching, on the one hand, and his development of a moral-metaphysics within the framework of The Awakening of Faith, which signifies a total commitment to the transcendental-analytic approach, on the other hand. In other words, Mou's identification of the School of Mind (xinxue 心學) as Confucian orthodoxy is incompatible with his classification of the doctrine of the tathägatagarbha as a nonperfect teaching. In particular, both are understood by Mou as different forms of transcendental idealism. As Chan also points out, in attempting to overcome such an inconsistency, Mou introduces a distinction of the discriminative and the nondiscriminative discourse. However, Chan shows that the failure of such a remedy might point to a fatal limitation of Mou's transcendental-idealist Confucianism as well.

These articles indicate, indirectly or directly, ways that Chinese Buddhism has exercised great influence upon the development of 
contemporary Confucian thought. As a running remark, one should also note that Mou's understanding of the distinction between Wang Yangming's 王陽明 (1472-1529) and Liu Zongzhou's 劉宗周 (15781645) school might be based on Zhiyi's syncretism of the different paths of Buddhist teaching. According to Zhiyi, there are four paths: (i) the sudden path, (ii) the gradual path, (iii) the secret path, and (iv) the indeterminate path. For Mou, while the first two paths represent a "manifest" teaching, the last two paths signify the "esoteric" teachings. This might inspire Mou to identify Wang's system as a "manifest" (xian 顯) teaching, and Liu's system as an "esoteric" ( $m i$ 密) teaching. The limitations of Mou's efforts, nevertheless, should not prevent us from appreciating Mou's significant contributions to enriching the conceptual apparatus of Confucianism with the various Buddhist doctrines. Overall, despite his denial of the Buddhist influences on the rise of Song-Ming Neo-Confucianism, Buddhism ironically provides new perspectives for Mou in developing Contemporary NeoConfucianism. But even within the field of Buddhist studies, Mou's legacy should not be undermined. As a positive example, his ontological interpretation of the Tiantai School enables us to defend Chinese Buddhism against Critical Buddhism. ${ }^{1}$

BROCK UNIVERSITY

St. Catharines, Canada UNIVERSITY oF TORONTO

Toronto, Canada

\section{ENDNOTE}

1. For this, please see Wing-cheuk Chan, "Two Dogmas of Critical Buddhism," Journal of Chinese Philosophy 37, no. 2 (2010): 276-94. 